Pre-publication draft. Accepted for presentation at the inaugural workshop of the International Society for Nietzsche Studies, University of Bonn, June 24-25, 2016, and for publication in Inquiry.

\title{
Attitudes to suffering: Parfit and Nietzsche
}

Christopher Janaway

\begin{abstract}
Derek Parfit's On What Matters provides a new opportunity to illustrate Philippa Foot's remark that "a confrontation with Nietzsche is a difficult thing to arrange." Parfit tries to show that Nietzsche does not disagree with central normative beliefs that "we" hold. This matters because fundamental disagreement in normative beliefs threatens Parfit's claim that normative beliefs are known by intuition. However, Nietzsche defends a plausible conception of well-being that challenges Parfit's central normative claims, in particular that suffering is bad in itself for the sufferer, by which Parfit means that intrinsic facts about suffering count objectively in favour of our not wanting it. Nietzsche recognizes the genuine phenomenon of "growth through suffering" as essential to well-being. Hence the removal of all suffering would lead to diminished well being. Parfit claims that if (counterfactually) Nietzsche understood normative concepts in Parfit's sense, then he would not disagree with the claim that suffering is bad in itself. I argue that if Nietzsche used the Parfittian normative concept $\mathrm{bad}$, he would not agree that intrinsic facts about suffering count in favour of our not wanting it. Suffering for Nietzsche is not merely instrumentally necessary for psychological growth, nor is it easy to construe it as something bad in itself that contributes value as part of a good whole. Suffering that can be given meaning through growth is something we have reason to want. Suffering that remains brute and uninterpreted is something we have reason not to want. But suffering as such has no invariant value across all contexts.
\end{abstract}




\section{Attitudes to suffering: Parfit and Nietzsche}

Some time ago Philippa Foot wrote "How is it ... that philosophers today do not even try to refute Nietzsche, and seem to feel morality as firm as ever under their feet? ... Part of the answer seems to be that a confrontation with Nietzsche is a difficult thing to arrange" (Foot 2001, 210-11). Derek Parfit's much-acclaimed book On What Matters provides a new opportunity to explore this issue. Towards the end of the second volume of that work Parfit dedicates a substantial chapter to Nietzsche, in which he tries to show that Nietzsche disagrees less than might be thought with central normative beliefs that "we" all, or nearly all, hold, and which Parfit believes we can know by intuition. Parfit's writing on Nietzsche is unlike much that occurs in studies of Nietzsche nowadays. Where even "analytical" writers on Nietzsche tend to show a fair degree of concern for historical or interpretive issues, Parfit approaches Nietzsche's writings largely as bearing on his own concerns. He principally wants to know whether "in ideal conditions, we and Nietzsche would have agreed" in our normative beliefs (Parfit 2011b, 570), and to that end he cites or paraphrases over a hundred short extracts from various sources in succession, many from the Cambridge Writings from the Late Notebooks volume, and judges them for their truth, plausibility, profundity, or helpfulness in the context of his own inquiry. But if Parfit's approach appears old-fashioned and naïve by current standards of scholarship, it also has a refreshing aspect. One can be over-meticulous or even reverential about the texts, and excessively sympathetic towards their author. Parfit avoids the first pitfall and asks directly what Nietzsche's significance is for moral philosophy. As for the pitfall of excessive sympathy, while he acknowledges the real sufferings Nietzsche underwent in his life, Parfit nonetheless reminds us of what we do not always trouble to recall: that Nietzsche says shocking things that most readers will not remotely agree with, and that there is something disturbing in the fact that a sensitive and thoughtful man such as Nietzsche contrived this elaborate verbal violence and manifested such apparent disdain towards human beings in general.

However, I shall argue that Parfit misinterprets the state of play between Nietzsche and himself. Nietzsche consistently defends a plausible conception of well-being that calls 
into question certain central normative claims Parfit believes we can know to be true by intuition, in particular the claim that suffering is bad in itself. This fundamental disagreement in normative beliefs challenges Parfit's claim that his (and "our") normative beliefs are known by intuition. If this is so, why is it important? First, because Parfit's work is in many ways a powerful summation of debates in recent analytical moral theory; secondly, because Parfit considers Nietzsche "the most influential and admired moral philosopher of the last two centuries", and expresses his own admiration for Nietzsche (2011b: 570-1). But if Parfit's discussion misses distinctive features of Nietzsche's work, it does not really confront Nietzsche as such, but rather perpetuates - and by virtue of the depth and prominence of its own moral theorizing becomes emblematic of — the more general impasse between Nietzsche and moral theory that Foot identified.

There is a broader sense in which Parfit does not confront Nietzsche. He does not engage with what is arguably Nietzsche's main claim to fame, the method of genealogy, which, as Bernard Williams has said, is "likely to reveal a radical contingency in our current ethical conceptions" that "seems to be in tension with something that our ethical ideas themselves demand, a recognition of their authority" (2002, 20-1). There has been much dispute concerning the question how Nietzschean genealogy is supposed to be, or to enable, a critique of our values, ${ }^{1}$ and debates about whether answers to questions about the origins of morality could or should affect our current attitudes are far from settled. Yet Parfit sidesteps all such issues, saying:

Nietzsche makes some fascinating claims about the origins of morality, especially Christian morality, and he sometimes suggests that these claims undermine morality. But as Nietzsche himself sometimes points out, that is not so. When we learn about the origins of morality, or of many other features of human life, we learn very little

\footnotetext{
${ }^{1}$ For a variety of views see Nehamas 1985, 107-13; Williams 2002, 20-40; Leiter 2002, 165-192 ; Foucault 2001; Geuss 2001; Prinz 2007, 215-43; Janaway 2007, 9-14; Doris 2009; Kail 2011.
} 
about the present state, or value, of things. In Nietzsche's words, “The more insight we possess into an origin the less significant does the origin appear" (Parfit, 2011b, $583)$.

This is inadequate. The sentence quoted here is from Daybreak, section 44, written before Nietzsche's conception of genealogy reached maturity, and in a passage that is arguably about something other than genealogy. ${ }^{2}$ Other evidence shows that in Nietzsche's view genealogy can "undermine" morality, at least to the extent of providing grounds for suspicion towards our own moral intuitions. This is a widespread, traditional understanding of Nietzsche's significance. ${ }^{3}$ I am not suggesting that Parfit could have no reply to the challenge of genealogy, merely that he has not acknowledged it, and thus has not engaged Nietzsche on Nietzsche's own territory, so to speak. In this respect he bypasses Nietzsche, as moral theorizing has often done. But then, by his own lights, he bypasses the most influential and admired moral philosopher of the last two centuries. So there is reason for Parfit to diminish

\footnotetext{
${ }^{2}$ According to a reading of the passage by Raymond Geuss, Nietzsche is here rejecting the "myth of origins," the idea that in investigating the past we might discover some privileged authority for our present interests and valuings. The point is that we cannot rely on the past to validate or vindicate what we now believe in: "our forms of valuation can get less and less purchase the further back towards the 'origins' we move" (Geuss 2001, 326). Geuss calls this "tracing a pedigree," and makes the point that "[g]iving a 'genealogy' is for Nietzsche the exact reverse of ... 'tracing a pedigree"' (Geuss 2001, 322). If that is right, this passage leaves Nietzsche's genealogical method untouched and Parfit has given no reason to think that in Nietzsche's view genealogical claims do not undermine morality.

${ }^{3}$ Brian Leiter reminds us of Ricoeur's characterization (Ricoeur 1970, 32) of Nietzsche, along with Marx and Freud, as "thinkers who taught us to regard with suspicion our conscious understandings and experience, whether the deliverances of ordinary psychological introspection about one's desires ... or the moral categories political leaders and ordinary citizens apply to themselves and the social world they inhabit" (Leiter 2004, 74).
} 
either his confidence in his own procedure or his admiration for Nietzsche. In what follows, however, the question is rather whether Parfit successfully confronts Nietzsche on his (Parfit's) own territory.

\section{Agreeing and disagreeing about the value of suffering}

Commentators have long recognized the importance of the value of suffering for Nietzsche, beginning fairly obviously with his early work on tragedy, and continuing into his later critique of values, one of whose preoccupations is the "morality of compassion" with its apparent drive to eliminate all suffering. For Bernard Reginster, for instance, Nietzsche's central project has as its "ultimate object of revaluation ... the role and significance of suffering in human existence" (Reginster 2006, 185). The value or meaning of suffering matters greatly to Nietzsche. So it is appropriate that Parfit emphasizes the extent to which Nietzsche's words celebrate suffering as something of positive value. One such passage occurs in Beyond Good and Evil:

You want, if possible (and no "if possible" is crazier) to abolish suffering. And us? it looks as though we would prefer it to be heightened and made even worse than it has ever been! Well-being as you understand it — that is no goal [Ziel]; it looks to us like an end! [Ende] ... The discipline of suffering ... has been the sole cause of every enhancement in humanity so far (BGE 225).

Parfit comments that such passages "seem to conflict deeply with what most of [us] believe" (2011b, 571) - "what most of us believe" being, allegedly, that suffering is bad in itself. Yet he also asserts that Nietzsche merely "tried to believe that suffering is not bad" (2011b, 571), and that "[t]hough Nietzsche sometimes denies that suffering is bad, ... that is not his real view" (2011b, 26). Seeking Nietzsche's "real view" can be an over-optimistic mission. But my principal aim (addressed directly in Sections 3-5 below) will be to a reveal $a$ view about suffering that is Nietzsche's, and ask how, if at all, it is at odds with Parfit's. In advance of 
that discussion it may help to reflect briefly on the term 'suffering', and on Parfit's reasons for foregrounding the question whether Nietzsche agrees or disagrees with "us."

The term 'suffering' applies to many kinds of state and to those states in many degrees, as does Nietzsche's word Leiden. Nietzsche discusses physical pain, in particular when considering historical attitudes to punishment and cruelty (see GM II, 4-6), but his psychologist's eye roams widely over, for example, feelings of guilt, disgust, loss or grief, loneliness, disappointment or dissatisfaction, prolonged illness, catastrophic reversal of fortune, and the self-inflicted sufferings of the ascetic. Our judgements about the value of suffering may be influenced by which kinds we emphasize. In Reginster's account, for instance, "suffering is defined by resistance" (Reginster 2006, 177). The idea is that we will not only our ends, but also the overcoming of obstacles to their attainment, so that "if we value the overcoming of resistance, then we must also value the resistance that is an ingredient of it." " One example is: "Beethoven's musical achievements had to overcome the intrinsic resistance involved in breaking with traditional harmony, developing new forms of musical expression, struggling to articulate complex new musical ideas, and so on" (2006, 179). Here "suffering" can be paraphrased by "what is difficult, or as we might prefer to say, challenging" $(2006,177)$. Nietzsche claims, on this view, that we do — and should positively value challenges to our will, not its mere satisfaction, and Reginster claims that this idea is important in understanding the notion of will to power. Nonetheless, it is doubtful whether the positive value Reginster describes can transfer to everything usually covered by the term 'suffering'. First, paradigmatic kinds of suffering, such as those typically undergone in bereavement, torture, psychotic experiences or chronic illness may seem inadequately characterized just as "difficult" and "challenging." Secondly, although these sufferings are typically obstacles to the attainment of common aims, they are not essential parts or 'ingredients' of a consciously pursued purposive activity. Unlike the "resistances" to

\footnotetext{
${ }^{4}$ A related account is that of Katsafanas 2013, who argues that something like this structure is constitutive of all agency for Nietzsche and can generate substantive normative conclusions. For a good discussion see Poellner 2015.
} 
Beethoven's ends, they merely afflict a subject, in the sense of happening to her regardless of her aims.

Parfit's paradigm cases of suffering tend to be episodes of extreme physical pain (e.g. "the way the red hot iron feels" $(2011 \mathrm{~b}, 459,541))$ - though he also acknowledges that "mental suffering ... can be much worse than much physical pain"” (2011b, 569). His index contains "pain, agony, suffering" as one heading, and he easily moves from "pain" to "great pain ... a sensation that this person intensely dislikes" (2011b, 459-60, my emphases). The disliking is important here. The mere sensation alone might not be disliked, in which case the person would not be suffering: "When we are in pain, what is bad is not our sensation but our conscious state of having a sensation that we dislike. ... It is our hedonic likings and dislikings ... that make these conscious states good or bad" (2011a, 54). Agony, then, is a great pain that the subject intensely dislikes. For Parfit, the claim that "The nature of agony gives us a reason to want to avoid future agony" is an intuitively recognizable, irreducibly normative truth $(2011 \mathrm{~b}, 551)$. Indeed, on the first page of On What Matters this thought about agony is a prime example of such a normative truth, and it is pivotal later in an extended argument against a subjectivist view of reasons (2011a, 73-82). For now, however, I wish to stress simply the need to be alert to the breadth of the term 'suffering'. For instance, if Nietzsche disagrees with Parfit (and Parfit's "us") over the value of suffering, it need not be by virtue of thinking that the agony of grasping red hot irons is crucial to a good life.

But why does Parfit place such weight on the issue of Nietzsche's agreeing or not? In the overall scheme of things Parfit is engaged in countering the Argument from Disagreement, which challenges his claim that we have the intuitive ability to respond to objective reasons and to recognize some irreducibly normative truths (2011b, 544). If, under ideal conditions of unbiased, well-informed reflection, people would genuinely disagree in their normative beliefs, then, for Parfit, we would have to think "How could we be so special? And if none of us could recognize such normative truths, we could not rationally believe that there are any such truths" (2011b, 546). However, Parfit believes we shall not reach this position, and counters with the following claim: 
Convergence Claim: If everyone knew all the relevant non-normative facts, used the same normative concepts, understood and carefully reflected on the relevant arguments, and was not affected by any distorting influence, we would have similar normative beliefs $(2011 \mathrm{~b}, 570){ }^{5}$

The Convergence Claim is an empirical prediction, and Nietzsche comes into play because he appears to threaten its truth: he appears to disagree radically with many of our central normative beliefs. Hence Parfit's assertion that "in defending the Convergence Claim we cannot ignore Nietzsche” (2011b, 26).

Parfit focuses on a particular normative belief which he calls "the double badness of suffering":

all suffering is in itself both bad for the sufferer and impersonally bad (2011b, 569).

This is a normative belief because Parfit is using 'bad' in the "reason-implying" sense, such that something's being bad means that we have reason not to want it. And he defends an objectivist view about what it is for us to have such a reason: if something is bad in itself, intrinsic facts about it count in favour of our not wanting it. Parfit rejects subjectivist views of reasons, according to which our reasons depend on what we in fact desire, or what we would in fact choose if we were fully informed and fully rational. On the objectivist view, by contrast, that we would choose something if we were fully informed and fully rational is made true by the fact that we have reason to want it (2011a, 62-3). So if something is bad in

\footnotetext{
${ }^{5}$ Parfit gives other formulations (with my italics): “... we would nearly all have similar normative beliefs" (2011b, 25, 563); "we and others would have similar normative beliefs" (2011b, 546).
} 
itself, that it is so is for Parfit an irreducibly normative, objective truth, which we can come to know through intuition. ${ }^{6}$

The double badness of suffering, Parfit says, is "not yet universally recognized" as a truth, though he hopes that people who disagree will be brought round to it $(2011 \mathrm{~b}, 569)$. The lingering disagreement he especially has in mind hinges on whether we think suffering can be impersonally good when it is deserved. Parfit himself thinks no suffering can be deserved incidentally finding Nietzsche in explicit agreement with him on this. ${ }^{7}$ But some disagree here because they think suffering can be deserved when it functions as punishment.

Nonetheless, for Parfit, people who take that view cannot disagree with the other half of the double badness claim. They must hold that suffering is in itself bad for the sufferer - that is what is makes it good as a punishment, in their view.

The claim that suffering is in itself bad for the sufferer has particular salience for Parfit because he thinks it is unlike some other normative claims in that (a) it is "not vague" and (b) "we have already reached sufficient agreement about it" (2011b, 565). The stakes are high, in that case. If Nietzsche disagrees with this claim, and if his views seem at all persuasive, we may begin to doubt the claim that agreement on this score is already "sufficient." And if more people come to see things Nietzsche's way in future, the prediction of convergence is dented to some extent, and that, by Parfit's own lights, should diminish confidence in our having an intuitive ability to recognize normative truths. Hence Parfit's strategy: show that the philosopher who most seems to disagree with the badness in itself of suffering, does not really do so.

\section{The case for Nietzsche's not disagreeing}

Towards the end of his chapter on Nietzsche Parfit summarizes various grounds for a somewhat weaker claim, that "Our disagreements with him are less clear and deep than they

\footnotetext{
${ }^{6}$ This is a cumulative view built up through both volumes of On What Matters. But see especially 2011a, 31-57; 2011b, 433-9, 542-69.

${ }^{7}$ See Parfit 2011b, 583 (citing HA 34), and 593.
} 
seem" $(2011 b, 603)$. But some of his grounds for saying even as much as this seem questionable. Parfit claims, for example, that some of Nietzsche's pronouncements to the apparent effect that suffering is not bad are not sane. He also finds that Nietzsche contradicts himself. Both are rather hackneyed claims that single out Nietzsche unfairly. Yes, we encounter some "appalling” violent passages in Nietzsche's late work Ecce Homo which may suggest that "his mind was starting to disintegrate" (2011b, 579). However, the sanity of the late works of 1888 has been much debated, to little conclusive effect. Some would construe Nietzsche's virulent writing as literary irony or desperate, frustrated hyperbole in calculated pursuit of a persuasive purpose. Maybe there is a bit of all of these at work. But if we detect incipient disintegration, how much does it matter? As Aaron Ridley comments, "what is exaggerated may be true, or interesting, even when pitched at a level that can seem deranged" (Ridley 2005, ix). Besides, Nietzsche was sane enough when he wrote The Gay Science and Beyond Good and Evil, on which we shall chiefly rely in what follows. On self-contradiction Parfit comments: "Though Nietzsche makes several claims that contradict what most of us would believe, Nietzsche himself contradicts these claims. When he disagrees with himself, he does not clearly disagree with us" (2011b, 595). That is an odd thing to say. Parfit produces no evidence of Nietzsche propounding direct contradictions, merely of his stated views varying according to time and context. ${ }^{8}$ Not every passage in Nietzsche's oeuvre fits into a single diachronically stable philosophical position. But few authors could pass such a test across sixteen years of published writings, let alone their notebooks, and to apply it to Nietzsche's output in particular seems unwise. So I discount both insanity and self-

\footnotetext{
${ }^{8}$ For example, when discussing the founding of religions in a passage from 1882 (GS 319) Nietzsche complains that the religious do not subject their experiences to reason. In 1888 , discussing the significance of Socrates for the history of philosophy (TI, "The Problem of Socrates," 10), he complains that trusting reason as opposed to culturally acquired instincts is a sign of degeneration. Juxtaposing the passages, Parfit concludes that if someone thinks responding to reason is a route to "virtue and happiness" (2011b, 594), then Nietzsche "does not clearly disagree" with them.
} 
contradiction as reasons for believing that Nietzsche does not disagree with Parfit's view about suffering.

More promising prima facie for Parfit's case are passages in which Nietzsche looks to be claiming that suffering is good in itself, but on the dubious ground that everything is good, or can be made good by our affirming or welcoming it (2011b, 571). Nietzsche, we are told, "tries to believe that everything is good" under the distorting pressure of the need to come to terms with his own suffering, but reasons badly in the process (see 2011b, 571-2), with the corollary that the ideal conditions for testing Convergence are not met, and Nietzsche's disagreement can then be discounted. What is the evidence, though, for Nietzsche's holding suffering to be good, or for his holding everything to be good (let alone holding the former because of the latter)? Parfit cites notebook passages on "saying yes to existence" as a whole, on pain and suffering being "desirable for their own sake," or "part of the highest desirability,"9 the passage in Ecce Homo where Nietzsche admires Lou Salomé's poem, Hymn to Life, for conveying the message 'pain does not count as an objection to life' (EH, "Zarathustra," 1), and the well known passage on love of fate - "you do not want anything to be different, not forwards, not backwards, not for all eternity" (EH, "Why I am so clever," 10). Parfit apparently assumes that, for Nietzsche, if one were to love everything, say yes to everything, or not want anything to be different, then everything would be good, and $a$ fortiori one's sufferings would be good. However, it is unclear whether Nietzsche thinks so. Must things be good in order for us to love, want or affirm their presence? If so, does loving something for its goodness as a whole require each of its components to be good in itself? I can love a city or a person as a whole and want them to be just as they are, without its being the case that everything about them is good. Also, when Nietzsche talks of "saying yes to life, even in its strangest and harshest problems" (TI, "Ancients," 5), it is debatable whether a "harsh problem" must be construed as in itself a good component of someone's life. So it is not clear that Nietzsche "tried to believe that everything is good." 572). If Nietzsche has

\footnotetext{
${ }^{9}$ WLN pp. 135-6, note 7[38]; 173, note 10[3]; 207, note 11[30].
} 
differing views from Parfit about the value of suffering, it is not safe to dismiss them for resting on this dubious ground.

Finally, when it comes to specifically moral attitudes to suffering, Parfit claims that Nietzsche is unable to disagree with him directly: "Since Nietzsche assumes that moral claims express commands, he seldom if ever uses the concept that we can express in English with the phrase ought morally. So Nietzsche's claims cannot straightforwardly conflict with our beliefs about what we morally ought to do" (2011b, 589). Parfit makes a linguistic point here. The German verb sollen can be used, as Kant uses it in the phrase $d u$ sollst nicht: "thou shalt not," 11 to express a command. Commands cannot be true. But beliefs about what one ought to do or ought not to do, also expressible using sollen, can in principle be true. And on Parfit's view, some are, because (very roughly) some facts count decisively against anyone's rationally wanting to act in certain ways. In German, Parfit argues, one might confuse the two

${ }^{10}$ See 2011b, 589, 603. Parfit has a thematic, and seemingly idiosyncratic, view about what counts as disagreement: many contemporary theorists are said not to disagree with him (or do so "directly") because they do not use the same concepts. In a review of Parfit's book Mark Schroeder draws attention to this feature of Parfit's conception of disagreement:

Bernard Williams, for example, turns out to lack the concept of a reason. John Mackie turns out to fail to have thoughts about morality, rather than to believe that nothing is wrong. Christine Korsgaard lacks normative concepts. Simon Blackburn and Allan Gibbard's disagreement with Parfit? That's superficial, too - they don't have normative concepts either (Schroeder 2011).

In all these cases the theorist in questions holds some internal or subjectivist conception of a reason, according to which "all reasons are provided by certain facts about our present desires or values" (2011b, 432), rather than Parfit's objectivist conception (see, e.g., 2011b, 435). As Schroeder implies, the idea that in these cases there are no disagreements seems surprising. ${ }^{11}$ Groundwork, Preface (Ak. 4:389). At Ak. 4:419 Kant uses the form du sollt nicht, an archaic form which Schopenhauer $(2009,127)$ cites as betraying the Biblical origin of Kant's view of imperatives. 
kinds of claim, and think that the only way for there to be truths about what one ought morally to do is for there to be commands that one must obey. Schopenhauer, ${ }^{12}$ as Parfit mentions, is scathing about Kant's ethics on this point (as Anscombe was much later ${ }^{13}$ ), saying that once you cease to believe in a divine issuer of commands there can be no commands with unconditional authority. Schopenhauer takes this to show that morality is not prescriptive and involves no duties. Nietzsche plausibly owes something to Schopenhauer here, and so it is helpful to realize that if Nietzsche argued straight from the death of God to the non-existence of moral oughts, an equivocation between two ways of reading sollen might unravel his argument.

Does Nietzsche argue this way, though? In opposing the non-theistic ethics of George Eliot and the like he does say that 'Christian morality is a command; it has a transcendent origin; it is beyond all criticism, all right to criticism; ... it stands or falls along with belief in God' (TI, "Skirmishes," 5). So lapse of belief in the Christian God leaves a justificatory gap for a morality that wants simply to retain Christian moral beliefs about what ought or ought not to be done. But we need not read Nietzsche as saying that lapse of belief in God is by itself sufficient for us to conclude that there is nothing anyone morally ought to do. A more charitable reading of this passage, as Simon Robertson has suggested, has Nietzsche claiming that "without the religious framework ... one is not entitled to assume that morality is authoritative or that moral values should be retained" (Robertson 2012, 95). This reading is strengthened by the way Nietzsche himself frames his point:

When the English really believe that they "intuitively" [intuitiv] know all by themselves what is good and what is evil; and when, as a result, they think that they do not need Christianity to guarantee morality any more, this is just the result of the domination of the Christian value judgement and an expression of the strength and depth of this domination: so that the origin of English morality has been forgotten, so

\footnotetext{
${ }^{12}$ Schopenhauer 2009, 125-30. (See Parfit 2011b, 586).

${ }^{13}$ Anscombe 1958.
} 
that no one can see how highly conditioned its right to exist really is. For the English, morality is not a problem yet ... (TI, "Skirmishes," 5).

Nietzsche's point here is genealogical, and seems pertinent to Parfit, who precisely holds that "we have intuitive abilities to respond to reasons and recognize some normative truths" (2011b, 544), moral truths among them. For Nietzsche the adherents of "English morality" have a strong sense of the intuitiveness of their core beliefs, but that sense can be explained in light of its origin. It is because our present intuitions became fixed through past confidence in the authority of religious doctrine that we came to hold our beliefs so firmly. It is because we forget that history that we now think they are unconditionally authoritative. Nietzsche is not assuming that 'ought morally' expresses a command. Rather he is at his characteristic task of "spoiling" our confidence in our present attitudes. ${ }^{14}$

Still, Parfit's claim that Nietzsche "seldom ... uses the concept we can express in English with the phrase ought morally" may yet be true, even if Nietzsche does not assume that 'ought morally' expresses a command. Quite early on, in Human, All too Human, Nietzsche was prepared to announce that 'morality, insofar as it was an 'ought', has been annihilated by our mode of thinking" (HA I, 34). In Daybreak he denies that there are any moral reasons for doing or avoiding anything (D 103). And the thrust of his later idea of moving "beyond good and evil" is to urge us not to make moral judgements. So let us assume a bolder premise, and say that Nietzsche never uses (as opposed to mentioning) the concept ought morally or any equivalent. He never asserts of anything that anyone ought morally to do it or not to do it. Then, according to Parfit, his beliefs are in no position to disagree directly (or "conflict straightforwardly") with a belief that "Everyone ought morally to avoid or prevent suffering." However, that leaves plenty of room for disagreement. Nietzsche disagrees by virtue of holding that such a claim, however analysed, is not true. And given that this disagreement is grounded in his denial that 'ought morally' can truly be predicated of anything, it is a disagreement that matters.

\footnotetext{
${ }^{14}$ For this notion of spoiling (verleiden) see GS 335.
} 


\section{Growth through suffering}

In pursuit of a "real view" of Nietzsche's concerning the value of suffering, let us consider some more substantial evidence that Parfit does not mention. In The Gay Science we find the following lucid reflections:

What we most deeply and most personally suffer from is incomprehensible and inaccessible to nearly everyone else; here we are hidden from our nearest, even if we eat from the same pot. But whenever we are noticed to be suffering, our suffering is superficially construed; it is the essence of the feeling of compassion that it strips the suffering of what is truly personal: our "benefactors" diminish our worth and our will more than our enemies do. In most cases of beneficence toward those in distress there is something offensive in the intellectual frivolity with which the one who feels compassion plays the role of fate: he knows nothing of the whole inner sequence and interconnection that spells misfortune for me or for $y o u$ ! The entire economy of my soul and the balance effected by "misfortune," the breaking open of new springs and needs, the healing of old wounds, the shedding of entire periods of the past — all such things that can be involved in misfortune do not concern the dear compassionate one: they want to help and have no thought that there is a personal necessity of misfortune; that terrors, deprivations, impoverishments, midnights, adventures, risks, and blunders are as necessary for me and you as their opposites; indeed, to express myself mystically, that the path to one's own heaven always leads through the voluptuousness of one's own hell. No, they know nothing of that: the "religion of compassion" (or "the heart") commands them to help, and they believe they have helped best when they have helped most quickly! Should you adherents to this religion really have the same attitude to yourselves that you have towards your fellow men; should you refuse to let your suffering lie on you even for an hour and instead constantly prevent all possible misfortune ahead of time; should you experience suffering and displeasure as evil, hateful, deserving of annihilation, as a defect of 
existence, then you have besides your religion of pity also another religion in your hearts, and the latter is perhaps the mother of the former - the religion of snug cosiness [Behaglichkeit]. Oh, how little do you know of the happiness of man, you comfortable and good-natured ones! For happiness and unhappiness are two siblings and twins who either grow up together or — as with you — remain small together! (GS 338).

There are minor translation problems here. The word Mitleid is translated both as "pity" and “compassion”; and Unglück as both 'unhappiness' and 'misfortune'. We could be led in different directions here. The questions "Is it good for me to receive pity over a misfortune?" and "Is it good for me to receive compassion over an unhappiness?" could well elicit different answers. So let us assume, as the passage seems to require, that Unglück is a state in which suffering is felt, and that Mitleid is a response to suffering which evaluates it negatively and is normally linked to motivational states that aim at prevention or alleviation.

Nietzsche speaks of the "religion" of pity or compassion. Although this insinuates that the attitude he is questioning has a cultural origin in a notion of Christian charity, the "dear compassionate one" need not be a religious believer. Rather, the notion of a "religion" appears to connote unquestioning adherence to a fixed, putatively authoritative principle, which I suggest must be at least something like the following:

(S) In all cases where a human being is or may be suffering, it benefits that human being to prevent, remove or diminish that suffering.

(S) would provide a general reason to prevent, remove or diminish any suffering, merely on the basis that it is a suffering. But Nietzsche denies (S). ${ }^{15}$ First he argues that people are led to

${ }^{15}$ It would an over-reading to impose any more nuanced principle than (S) on the text of GS 338. But note that Nietzsche's denial of (S) is not sufficient to challenge Parfit's view of suffering: Parfit can also deny (S), given that some sufferings can be instrumentally good, 
accept (S) for bad reasons. Compassionate helpers assume that removing suffering is as such beneficial for the sufferer, but thereby fail to take account of a value of suffering for the sufferer that is "hidden" or "truly personal." We might say that this kind of helper is typically unable to place particular sufferings in the sufferer's own narrative, in which they may have a particular significance. ${ }^{16}$ For the sufferer, undergoing particular sufferings may re-configure their attitudes in ways that are important to them. They may understand things differently, begin to feel different emotions, be released from feeling other emotions, change their selfconception, develop new capacities and find a meaning in the course of events or in their life as a whole. Assuming that these are benefits to the sufferer, and that undergoing particular sufferings is a necessary condition of these benefits, (S) is false. (S) masquerades as true, however, to those who seek only a generalizable value for any suffering merely qua suffering, and who thereby implicitly erase the particular, personal or "hidden" value from the picture.

Nietzsche's second point is that if one applied (S) to one's own case, finding only a generic negative value in one's actual or possible sufferings, one would be assigning overriding value to a state of Behaglichkeit, a comfortable, cosy state, free from all danger or risk. In fact, this conception of well-being as safety from danger may be foundational here, the "mother" of the principle of compassionate helping. It is not a compulsory conception of well-being, merely factually the prevalent conception. Elsewhere he questions its value:

and removing an instrumentally good suffering may not be beneficial to the sufferer. However, as I shall argue, Nietzsche's grounds for denying (S) raise considerations that go against Parfit's view.

${ }^{16}$ There seems to be a parallel thought in GS 277: "be it what it may — bad or good weather, the loss of a friend, a sickness, slander, the absence of a letter, the spraining of an ankle, a glance into a shop, a dream, a fraud - it shows itself immediately or very soon to be something that 'was not allowed to be lacking [nicht fehlen durfte]' — it is full of deep meaning and use precisely for us!" 
Behind the basic principle of the current moral fashion: "moral actions are actions performed out of sympathy [Sympathie] for others," I see the social drive of timidity [Trieb der Furchtsamkeit] hiding behind an intellectual mask: this drive desires, first and foremost, that all the dangers which life once held should be removed from it, and that everyone should insist in this with all his might: hence only those actions which tend towards the common security and society's sense of security are to be accorded the predicate 'good'. - How little joy people must nowadays take in themselves when such a tyranny of timidity prescribes to them their supreme moral law, when they so uncontradictingly allow themselves to be ordered to look away from themselves but to have lynx-eyes for all the suffering and distress that exists elsewhere! Are we not, with this tremendous objective of obliterating all the sharp edges of life, well on the way to turning mankind into sand? Sand! Small, soft, round, unending sand! Is that your ideal, you heralds of the sympathetic affections? (D 174, translation amended).

The allegation is that in conceiving well-being as absence of suffering, we are driven by an emotional need to treat humans as primarily passive beings who require protection from their surroundings, and that so treating them is liable to promote dullness and uniformity. Nietzsche points out that in fact, to the contrary, we positively value in human beings the active capacity to create, to transform, or give new forms and meanings to things, including ourselves. But this capacity is liable to be valued less, and exercised less, to the extent that a community accepts the evaluation of suffering represented by our earlier principle $(\mathrm{S})$. As a consequence the individual's capacity for self-development and creative achievement is not promoted.

In Beyond Good and Evil Nietzsche turns the tables on the "religion of pity", saying that, while it seeks to protect the passive "creature in the human being," he has pity for the potentially transformative "creator" character of human beings that stands to be stifled through adherence to something like our principle (S). Hence, to its adherents, he exclaims "Well-being as you understand it — that is no goal; it looks to us like and end!" (BGE 225). 
To "measure the value of all things according to pleasure and pain" is to measure them "according to incidental states and trivialities," because "there are problems that are higher than any problems of pleasure, pain and pity; and any philosophy that stops with these is a piece of naiveté" (BGE 225). (Thus when Parfit begins his whole project with the statement that "on any plausible theory [of well-being] hedonism covers at least a large part of the truth" (2011a, 40), real disagreement is already brewing.)

The presence of suffering, and of an attitude of acceptance which "allows your suffering to lie on you," promote what Nietzsche considers a superior kind of well-being. Other passages show the contrast clearly — for example:

if we ... want to transcend our own pity and thus achieve victory over ourselves, is this not a higher and freer viewpoint and posture than that in which one feels secure when one has discovered whether an action benefits or harms our neighbour? We, on the other hand, would ... strengthen and raise higher the general feeling of human power, even though we might not attain to more. But even this would be a positive enhancement of happiness (D 146).

In Gay Science 338 Nietzsche's alternative conception of well-being employs the concept of personal growth. If you and your community adopt (S) religiously, your happiness will not grow, he says, but remain small. It is not easy to specify what this growth consists in. But it would appear to involve enhancement of one's capacities to understand and make sense of one's experiences, to assign coherent narrative significance to them, and to feel a sense of power. Nietzsche claims that if we subscribe to principle (S), we are failing to recognize that this form of growth belongs to well-being, and that experiences of suffering are necessary for this form of growth to occur. Acting upon $(\mathrm{S})$ would tend to diminish well-being both in the case of others' suffering and one's own.

These views of Nietzsche's are, I suggest, readily intelligible, and they are not his alone. He was remarkably prescient of some views in contemporary psychology, where since 
the 1990s empirical study has tended to confirm the occurrence of what is called posttraumatic growth. To quote from one of its proponents:

Psychologists now realize that it is naïve to seek to live a life in which there is no sadness, and no misfortune, and hence that the pursuit of happiness must include learning how to live with, and learn from, adversity. ... psychological well-being refers to ... autonomy, a sense of mastery, personal growth, positive relations with others, self-acceptance, and purpose in life (Joseph 2011, 14-17).

Many studies appear to confirm the claim that traumatic experience can enhance psychological well-being so conceived. Nietzsche's conception of well-being looks similar: we have seen personal growth literally mentioned in the passage from Gay Science, 338, and four of the other aspects of well-being here - autonomy, sense of mastery, self-acceptance, and purpose in life — are paralleled by passages in his writings. ${ }^{17}$

The case studies in this post-traumatic growth literature are exemplified by that of a woman who had suffered a sexual assault, saying of it "it was a turning point .... If I was to erase the past then I wouldn't be who I am today" (Joseph 2011, 70). Similarly the professor of psychiatry Kay Redfield Jamison wrote of her own severe experiences of bipolar disorder, that, given the choice of having the condition or not having it: "Strangely enough I think I would choose to have it .... Because I honestly believe that as a result of it I have felt more

${ }^{17}$ See GS, Preface, 3: "self-mastery” (Herrschaft über sich); GM 1 10: “yes-saying to oneself" (Ja-sagen zu sich selber); GS, 335: "human beings who ... give themselves laws"; GS, 347: "a delight and power of self-determination" (Selbstbestimmung); GM III, 1: "the basic fact of the human will: ... it needs a goal". "Positive relations with others" may seem an exception, since Nietzsche tends to conceive post-traumatic well-being more in terms of the strength to love one's isolation from others. However, he does regard self-cultivation as a route to benefiting others, and contrasts it favourably with over-concern about protecting others from harm. See D 174, GS 290. 
things, more deeply; had more experiences, more intensely .... I have been aware of finding new corners in my mind and heart." 18 This seems close to the kind of attitude to suffering Nietzsche had in mind when he aspired to "say yes to life even in its strangest and harshest problems," and thought of rejoicing at the return of one's life in every detail without wanting to exclude its sufferings. Nietzsche's own illness gives him opportunity to be his own case study:

I doubt that such pain makes us "better" — but I know that it makes us deeper. ... one emerges from such dangerous exercises in self-mastery as a different person, with a few more question marks, above all with the will henceforth to question further, more deeply, severely, harshly, evilly, and quietly than one had previously questioned (GS, Preface, 3).

Suffering then can enhance well-being, if one conceives well-being as Nietzsche conceives it. Finally, Nietzsche believes that human beings already operate with an attitude to suffering compatible with his conception. As he observes in the Genealogy,

Man ... does not negate suffering in itself: he wants it, he even seeks it out, provided one shows him a meaning for it, a "for-this" $" 19$ of suffering. The meaninglessness of suffering, not the suffering itself, was the curse that thus far lay stretched out over humanity (GM III, 28).

It is a reasonable assumption that if something contributes to someone's well-being, then it is good for them, and if it is detrimental to their well being, it is bad for them. So if Nietzsche has an intelligible conception of well-being, we are entitled to read him as holding that things can be good or bad for someone in light of that conception. One way of regarding

\footnotetext{
${ }^{18}$ Jamison 1997, 218-19. I owe the quotation to Roberts 2008, 745-6.

${ }^{19}$ ein Dazu des Leidens. Amended from the published translation.
} 
Nietzsche's view is as follows. If a course of events - say, a life, or some portion of a life instantiates as a whole what we can call growth-through-suffering, it may contribute to a recognized form of well-being. Such a course of events can both be good as a whole and have suffering as an indispensable component. We fail to understand this and substitute an inferior conception of well-being, if we uphold principle (S) "religiously," believing that every instance of suffering is to be removed or prevented. A life cleansed of suffering would be low on well-being, a stunted life.

\section{Bad parts of good wholes}

However insightful we find the considerations raised in the previous section, they may not be conclusive against the claim that suffering is bad in itself in Parfit's reason-implying sense. For something we have reason not to want can make a contribution to some wider state of affairs that we have reason to want. We may endure something that in itself is bad, as a necessary condition of some overall good's obtaining. So, accepting that Nietzsche identifies the distinctive good that we have called growth-through-suffering, and that suffering is a necessary condition for the occurrence of growth-through-suffering, it may yet be the case that in itself suffering is bad for the sufferer. If so, perhaps the most we can conclude from Nietzsche's line of thought is that we do not always have decisive reason not to want suffering.

One obvious way for this to be the case is if suffering is assigned a merely instrumental value. Suffering that is bad in itself (say, a painful medical procedure) can clearly be a means to an end that is good in itself, and need not trouble Parfit. Parfit (2011b, 571) interprets some of Nietzsche's utterances as claims that suffering is instrumentally good: for instance, the assertion in Beyond Good and Evil that "profound suffering makes noble" (BGE 270). We might add the similar-sounding "The discipline of suffering ... has been the sole cause of every enhancement in humanity so far" (alle Erhöhungen des Menschen bisher geschaffen hat, BGE 225). If Nietzsche's thought is that abolishing suffering from life would be undesirable because it can be a cause of enhancements, then he need not disagree with 
Parfit's belief that all suffering is in itself bad. Well-being can be enhanced by courses of events in which suffering, though bad in itself, causes good outcomes.

Nietzsche has no more reason than anyone to deny that suffering can be instrumentally good. However, the position represented by Gay Science 338 does not collapse into that view. Consider, for example, the admittedly rather obscure notion of 'letting your suffering lie upon you', which at least must involve standing in an attitude to the suffering. If, as seems likely, growth-through-suffering encompasses a range of further attitudes towards the suffering, such as "mastering" or "affirming" it, or coming to understand or learn about it, interpreting or giving a meaning to it, then the relation of the suffering to the growth is not the causal necessity characteristic of suffering that is merely a means to a good end. (By contrast, the value we typically assign to painful medical treatment is not owed to any interpretation or meaning the patient gives it.) But it is still not clear whether the overall good of growth through suffering conflicts with suffering's being bad in itself. In deciding that issue a distinction made by G.E. Moore may provide some help. Moore distinguishes two ways in which something bad in itself can be a necessary condition for some overall good. In addition to the case where something is necessary as a means to a good effect, there is the case of what Moore calls an organic whole. ${ }^{20}$ Here is how Moore explains the contrast. When something is a means to something good, its relation to the good is "merely a natural or causal necessity," so that if the laws of nature allowed it, the "utter annihilation" of the means "would leave the value of that which it is now necessary to secure entirely unchanged." That is to say, the good end, if caused in some other way, would still be good. By contrast, in the case of an organic whole "the good in question cannot conceivably exist, unless the part exist also. The necessity which connects the two is quite independent of natural law" (Moore 1993, 81). In this case that which is good (the whole) could not survive the absence of any of its parts.

\footnotetext{
${ }^{20}$ Moore 1993, 78-88. I owe to Zaibert 2014 the observation that Parfit appears to ignore the conception of an organic whole developed by Moore in this passage.
} 
It seems to make better sense of Nietzsche's growth-through-suffering to view it as a good organic whole of which suffering is a part, rather than as a good end to which suffering is a means. However, that still leaves open the possibility that suffering is bad in itself. For in the Moorean conception the value of an organic whole is not equal to the sum of the values of its parts. It is not simply a case of accumulating contributory amounts of good. Removing suffering would mean completely destroying the good whole that is growth-throughsuffering, but the contribution of a part to a good whole is compatible with the part's not being good in itself, and in principle even with the part's being bad in itself. I say "in principle" to reflect Moore's own rather qualified view: "Whether the addition of a bad thing to a good whole may increase the positive value of the whole, or the addition of a bad thing to a bad may produce a whole having positive value, may seem ... doubtful; but it is, at least possible" (Moore 1993, 79). So if growth-through-suffering is an organic whole of this kind, the Nietzsche of Gay Science 338 does not have to deny that suffering is bad in itself.

Other, more direct considerations might push us towards the view that Nietzsche must construe suffering as bad in itself. Take the person who has achieved well-being through suffering: say, a bipolar sufferer similar to Jamison. Let us accept that it was good for her that she suffered precisely what she suffered, in that her bipolar episodes played an indispensable role in her growth as a person, enabling her to understand and feel more deeply. Her life would have been worse without her mental sufferings. Now we might recoil somewhat: it is all very well for our subject to take this rosy attitude to her sufferings retrospectively, but if we return her to her state before the onset of those particular sufferings, she would have dreaded the prospect of them, would not in any way have wanted them, and would almost certainly have tried to prevent them if possible. While she was undergoing these experiences the same negative attitudes would have been present, only more deeply felt. So it is hard to see how in these cases she could then have regarded the occurrence of her suffering as in any way good. Taking the suffering all by itself, outside of any "growth-through-suffering" sequence, would she (or any of us) not have reason not to want it - i.e. would it not be bad in itself, whatever other good it eventually contributed to? Secondly, the bipolar sufferer's experiences (and likewise any sufferer's experiences) might in fact not have enabled her to 
find meaning, achieve growth, or however we characterize it. It is obvious that many sufferings remain unredeemed in this way. People who suffer can die or become otherwise incapable before their sufferings have a chance to become part of a "growth" sequence. Or their sufferings can remain brute and undigested features of their life from which nothing is gained. Surely the mere facts about these unredeemed sufferings would count in favour of the subject's not wanting them? Such thoughts may make it seem plausible that suffering is in itself bad for the sufferer, even given Nietzsche's views in Gay Science 338. For if unredeemed suffering is, simply qua suffering, bad in itself — intrinsically bad — for the sufferer, it cannot be that the same sufferings, had they been part of a Nietzschean growththrough-suffering sequence, would somehow not have been bad in themselves. At least, Moore's conception of an organic whole dictates this much, because the intrinsic value of a part of such a whole is invariant: it cannot have one intrinsic value when it is part of a whole and a different intrinsic value when it is not.

If Nietzsche held that the suffering that is an indispensable part of growth-throughsuffering is nonetheless bad in itself, would he be in agreement with Parfit after all? On the simple claim that suffering is bad in itself, Yes. But Nietzsche also claims that well-being is enhanced by having in your life the kind of good state of affairs for which suffering is a (noncausally) necessary condition. And that suggests that suffering sometimes, in some contexts, is something we have reason to want. At any rate, for Nietzsche, trying to prevent ourselves from suffering would be detrimental to our well-being. So on this view Parfit's statement that suffering is bad in itself is at best incomplete or misleading. We do not have reason to wish suffering absent, or perhaps even to wish it diminished - even if it is bad in itself.

However, this Moorean picture of Nietzsche's position involves a certain degree of internal strain. We have to believe that our lives become impoverished - worse - simply by failing to contain things that are always in themselves bad for us. How are we to explain this? The picture has it that suffering is invariant in value, bad in itself in the context of any whole. Its presence is non-instrumentally necessary to the existence of some good wholes, and it is also part of some bad wholes, but its own invariant value gives no explanation of how it contributes differentially to the value of these wholes. We seem to have reason to want 
suffering in many contexts, but not in others, even though its own value never changes and it always gives us reason not to want it. Jonathan Dancy has argued that Moore's picture is flawed in general, in that it

commits one to saying ... that though there is no reason to preserve the part as a part [or in our case: there is reason not to preserve the part as a part], there is a reason to protect the whole, and that reason derives from the presence of the part. Now this does sound incoherent. Surely we have reason to protect the part here, if it is contributing value (Dancy 2003, 631).

Dancy argues that to remove this difficulty, we should accept that a part may vary in value as it 'moves from whole to whole' (Dancy 2003, 629). If this is so, then in principle the very same instance of suffering can be something we have reason not to want when it is part of one kind of sequence, and something we have no reason not to want (or even reason to want) when it is part of another. Nietzsche's view, I shall suggest, is of this kind: suffering is not, in itself, invariantly good or bad.

\section{Nietzsche genuinely disagrees}

If Nietzsche indeed denies that suffering is bad in itself for the sufferer, we reach an interpretation of Nietzsche's notion of growth through suffering that is preferable on two grounds: (1) it removes the strain inherent in the Moorean organic whole picture, and (2) it squares well with the textual evidence. The result is that Nietzsche genuinely disagrees with Parfit's most salient example of a normative truth knowable by intuition.

First, however, we must disarm the challenge posed once again by Parfit's suggestion that Nietzsche does not directly disagree with "us" to the extent that he does not use the same concepts. Parfit says, "I have mainly discussed beliefs that involve ... the reason-implying concepts good and bad.... Since Nietzsche seldom if ever uses these concepts, he seldom disagrees directly with these beliefs" (2011b, 603). But the last claim here is far from obvious. The point of the Genealogy's first essay, for instance, is to distinguish the morally- 
saturated concept evil from the concept bad (and to distinguish good from, in effect, morally good), and Nietzsche expressly wants to retain the concepts good and bad, in a non-moral sense: “"Beyond Good and Evil' .... At the very least this does not mean 'Beyond Good and Bad"' (GM I, 17). But is bad a reason-implying concept for Nietzsche? It is hard to see why not. In a much discussed passage from Daybreak he states that there are "other reasons than hitherto" for doing or avoiding some actions (D 103). And Nietzsche makes plentiful negative evaluations of his own: he asserts plainly and without qualification that many things are harmful, dangerous, disgusting, unhealthy, and so on - all ways, plausibly, of being bad. Things that are harmful or unhealthy need not be so universally — they may be harmful or unhealthy only for some human being or some type of human being. ${ }^{21}$ But if something is bad in one of these ways, a natural construal is that those human beings for whom it is bad have reason not to want it.

When Parfit asserts that something is bad in itself in the reason-implying sense, he means that intrinsic facts about it objectively count in favour of our not wanting it. It would be quite unfounded to impute this notion of reason-implying badness to Nietzsche, in the light of the passage in The Gay Science in which he says "Whatever has value in the present world has it not in itself, according to its nature ... but has rather been given, granted value, and we were the givers and granters!" (GS 301). ${ }^{22}$ Furthermore, it would be rash to credit Nietzsche with a commitment to there being intrinsic facts about things. ${ }^{23}$ However, Parfit

${ }^{21}$ Leiter 2002 argues persuasively that Nietzsche can (and, for his critique of morality, must) hold a realist position about what is good or bad for an agent. See also Hussain 2013, 396. But note that Leiter 2014 takes a different view, arguing that Nietzsche does not require this realist position.

${ }^{22}$ Note, however, that the "we" here applies not to all human beings, but to "higher human beings" who are "thinking-sensing ones" (die Denkend-Empfindenden), as opposed to "socalled practical human beings."

${ }^{23}$ In the light of KSA 12: 105 (2[85]): 'if we think other 'things' away, then a thing has no properties, i.e. there is no thing without other things"; and 353 (9[40]): "that things have a 
encourages us to imagine what Nietzsche would say if (counterfactually) he could be convinced to adopt Parfit's understanding of good and bad in the reason-implying sense: "we can try to predict whether, if we and Nietzsche had used the same concepts, and the other ideal conditions were met, we would have had similar normative beliefs" (Parfit 2011a, 590). If Nietzsche had used the concept bad in just the way Parfit uses it, would he have agreed that all suffering is in itself bad for the sufferer? I suggest not.

Textual evidence points to Nietzsche's denying the badness in itself of suffering. In The Gay Science 388 Nietzsche does not say that suffering, although evil and hateful, nonetheless contributes to the overall good of growth-through-suffering. He pointedly says that if you regard suffering "as evil, hateful, deserving of annihilation, as a defect of existence" you are making a mistake. The mistake arises from making a normative claim about suffering in isolation, paying no attention to the "whole inner sequence and interconnection" in which it stands. Again, he says that "Man does not negate suffering in itself," and that the "curse" is merely the presence of suffering that cannot be given a meaning (GM III, 28). We may still put the point in terms of wholes and parts. When we concentrate, like the "dear compassionate one," on assigning value to the suffering in itself in isolation, we miss the value that lies in the whole of which the suffering is a part and in which it acquires meaning for the sufferer. Wholes in which suffering is a necessary part of growththrough-suffering are good - they contribute to well-being — and wholes in which suffering remains simply brute, uninterpreted, unlearned-from, unredeemed suffering may well be bad, or something that that there is reason not to want one's life to contain. But that is compatible with suffering's being — invariantly and across all contexts — neither good nor bad in itself.

Further specification of Nietzsche's position is, I think, under-determined by the textual evidence. One view he might conceivably hold is that the "whole inner sequence and interconnection" is the sole bearer of value in growth through suffering, with the component tokens of suffering mere neutral occurrences, each lacking either positive or negative value.

constitution in themselves ... is a quite idle hypothesis: it would presuppose ... that a thing released from all relations would still be a thing." See also Nehamas 1985, 80-1. 
An objection to this view might be that the "curse" of meaningless suffering cannot just consist in the fact that something that has happened remains meaningless (as most occurrences surely do). The source of badness here is rather that you have suffered and are stuck with the suffering's meaninglessness. How would that be bad, if there is nothing bad about the episode of suffering as such? In response we may note that there are non-normative claims about suffering that may cloud the issue. For instance, it is true that suffering is negatively felt by the sufferer. For Parfit, suffering is always disliked. But these are arguably analytic truths, and at any rate they are not normative claims. Parfit is clear that when we dislike pain, it is not for any reason (2011a, 54-6). Secondly, it is true that human beings naturally tend to want to avoid suffering. This is a psychological or anthropological fact, and so also not a normative claim. When we thought earlier about people undergoing unredeemed suffering, we thought of them undergoing states that feel bad, and to which they are likely to have a clear aversion or resistance. But that is compatible with holding that no suffering taken atomistically is either good or bad in the reason-giving sense. On this view Nietzsche's denial of the badness of suffering could be summarized as "it is good to have in your life things that are bad." But rather than meaning "you have reason to want your life to contain some things that you have reason not to want," this would mean "you have reason to want your life to contain some things that feel bad and to which you naturally tend to be averse." ("Saying yes to life in its harshest problems" can perhaps be heard this way).

Another view compatible with Nietzsche's utterances is effectively that urged by Dancy: that suffering can be either good or bad in the reason-implying sense - can be something we either have reason to want or not to want - but that which value it has varies according to the context it is in. It seems plausible to regard Nietzsche's position at least as congenial to such a view, even if, as so often with Nietzsche, it is never stated in theoretical terms. Suffering that is part of a whole growth-through-suffering sequence is something we have reason to want, because its occurrence enhances our well-being. Suffering that is part of a sequence in which it remains meaningless is something we do not have reason to want, and may have reason not to want. If Nietzsche holds such a view, then he disagrees with Parfit. And, as we have argued, if he used the Parfittian concept bad in the reason-implying sense, 
Nietzsche would not agree that intrinsic facts about suffering as such objectively count in favour of our not wanting it. Nietzsche would then genuinely, and directly, disagree with Parfit.

\section{Conclusion}

Parfit states that Nietzsche's apparent disagreement with the badness in itself of suffering is something "we cannot ignore." If the disagreement is genuine, resulting from sane, unbiased, factually well-informed, rational reflection, we cannot be confident of our ability to know the truth of the normative claim "suffering is bad in itself." Parfit states that Nietzsche's real view is not in disagreement with that normative claim. But we have found Nietzsche to give a coherent and convincing description of growth through suffering, a genuine phenomenon that is attested by empirical psychology and recognizably based in a plausible conception of wellbeing. The necessity of growth through suffering for well-being makes it untrue, in Nietzsche's view, that suffering is bad in itself for the sufferer. His disagreement with Parfit is therefore not merely apparent. Parfit discounts as genuine disagreements cases where the putatively disagreeing parties are not using the same concepts. But he allows that we can at least ask whether they would agree, if they were using the same concepts. He claims that Nietzsche would not disagree with the badness in itself of suffering, if he used the Parfittian reason-implying concept $b a d$. We have given grounds for denying that. For Nietzsche suffering has no invariant reason-implying value across all contexts in which it occurs. When it occurs in the context of a "whole sequence and interconnection" that is growth through suffering, then - according to a plausible reading of Nietzsche - we have reason to want it, and reason not to eliminate it from our lives. According to Parfit himself, Nietzsche's disagreement matters. It poses a challenge to the Convergence Claim, and throws some doubt on Parfit's crucial belief that we can know normative truths by intuition. Parfit might be able to formulate some more complex normative claim about suffering upon which his intuitions and those of Nietzsche (and of "all of us") will one day converge, but in the material to hand he has not done so.

\section{Bibliography}


Anscombe, G.E.M. 1958. “Modern Moral Philosophy.” Philosophy 33: 1-19.

Dancy, Jonathan. 2003. “Are There Organic Unities?” Ethics 113: 629-50.

Doris, John. 2009. “Genealogy and Evidence: Prinz on the History of Morals.” Analysis 69: 704-13.

Foot, Philippa. 2001. "Nietzsche: the Revaluation of Values.” In Richardson and Leiter, Nietzsche, 210-20.

Foucault, Michel. 2001. "Nietzsche, Genealogy, History.” In Richardson and Leiter, Nietzsche, 341-59.

Geuss, Raymond. 2001. "Nietzsche and Genealogy.” In Richardson and Leiter, Nietzsche, $322-40$.

Hussain, Nadeem J. Z. 2013. “Nietzsche's Metaethical Stance.” In The Oxford Handbook of Nietzsche, edited by Ken Gemes and John Richardson, 389-414. Oxford: Oxford University Press.

Jamison, Kay Redfield. 1997. An Unquiet Mind: A Memoir of Moods and Madness. London: Picador.

Janaway, Christopher. 2007. Beyond Selflessness: Reading Nietzsche's Genealogy. Oxford: Oxford University Press.

Joseph, Stephen. 2011. What Doesn't Kill Us: The New Psychology of Posttraumatic Growth. New York: Basic Books.

Kail, Peter. 2011. “'Genealogy’ and the Genealogy.” In Nietzsche's On the Genealogy of Morality: A Critical Guide, edited by Simon May, 214-33. Oxford: Oxford University Press.

Kant, Immanuel. 1996. Groundwork of the Metaphysics of Morals. Translated by Mary J. Gregor. In Practical Philosophy, 41-108. Cambridge: Cambridge University Press.

Katsafanas, Paul. 2013. Agency and the Foundations of Ethics: Nietzschean Constitutivism. Oxford: Oxford University Press.

Leiter, Brian. 2002. Nietzsche on Morality. London: Routledge. 
Leiter, Brian. 2004. "The Hermeneutics of Suspicion: Recovering Marx, Nietzsche, and Freud.” In The Future for Philosophy, edited by Brian Leiter, 74-105. Oxford: Clarendon Press.

Leiter, Brian. 2014. "Moral Skepticism and Moral Disagreement in Nietzsche." Oxford Studies in Metaethics, vol. 9, edited by Russ Shafer-Landau, 126-51. Oxford: Oxford University Press.

Moore, G. E. 1993. Principia Ethica. Edited by Thomas Baldwin. Cambridge: Cambridge University Press.

Nehamas, Alexander. 1985. Nietzsche: Life as Literature. Cambridge, MA: Harvard University Press.

Nietzsche, Friedrich. 2002. Beyond Good and Evil. Edited by Rolf-Peter Horstmann and Judith Norman, translated by Judith Norman. Cambridge: Cambridge University Press. (BGE)

Nietzsche, Friedrich. 1997. Daybreak. Edited by Maudemarie Clark and Brian Leiter, translated by R. J. Hollingdale. Cambridge: Cambridge University Press. (D)

Nietzsche, Friedrich. 1988. Kritische Studien-Ausgabe. Edited by G. Colli and M. Montinari, 15 vols. Munich: Deutscher Taschenbuch Verlag/de Gruyter. (KSA)

Nietzsche, Friedrich. 1998. On the Genealogy of Morality. Translated by Maudemarie Clark and Alan J. Swensen. Indianapolis: Hackett. (GM)

Nietzsche, Friedrich. 2001. The Gay Science. Edited by Bernard Williams, translated by Josephine Nauckhoff and Adrian del Caro. Cambridge: Cambridge University Press. (GS)

Nietzsche, Friedrich. 2003. Writings from the Late Notebooks. Edited by Rüdiger Bittner, translated by Kate Sturge. Cambridge: Cambridge University Press. (WLN)

Nietzsche, Friedrich. 2005. The Anti-Christ, Ecce Homo (EH), Twilight of the Idols (TI) and Other Writings. Translated by Judith Norman. Cambridge: Cambridge University Press.

Parfit, Derek. 2011a. On What Matters, vol. 1. Oxford: Oxford University Press.

Parfit, Derek. 2011b. On What Matters, vol. 2. Oxford: Oxford University Press. 
Poellner, Peter. 2015. Review of Agency and the Foundations of Ethics: Nietzschean Constitutivism, by Paul Katsafanas. European Journal of Philosophy 23: 162-9. Prinz, Jesse J. 2007. The Emotional Construction of Morals. Oxford: Oxford University Press.

Reginster, Bernard. 2006. The Affirmation of Life: Nietzsche on Overcoming Nihilism. Cambridge, MA: Harvard University Press.

Ricoeur, Paul. 1970. Freud and Philosophy. Translated by D. Savage. New Haven: Yale University Press.

Richardson, John, and Brian Leiter, eds. 2001. Nietzsche. Oxford: Oxford University Press. Ridley, Aaron. 2005. Introduction to Friedrich Nietzsche, The Anti-Christ, Ecce Homo, Twilight of the Idols, and Other Writings, translated by Judith Norman, vii-xxxiv. Cambridge: Cambridge University Press.

Roberts, M. 2008. "Facilitating recovery by making sense of suffering: A Nietzschean perspective." Journal of Psychiatric and Mental Health Nursing 15: 743-48.

Robertson, Simon. 2012. "The Scope Problem: Nietzsche, the Moral, Ethical, and QuasiAesthetic.” In Nietzsche, Naturalism, and Normativity, edited by Christopher Janaway and Simon Robertson, 81-110. Oxford: Oxford University Press.

Schopenhauer, Arthur. 2009. Prize Essay on the Basis of Morals. In The Two Fundamental Problems of Ethics, translated by Christopher Janaway, 113-258. Cambridge: Cambridge University Press.

Schroeder, Mark. 2011. Review of On What Matters, by Derek Parfit. Notre Dame Philosophical Reviews. https://ndpr.nd.edu/news/25393-on-what-matters-volumes-1and-2/

Williams, Bernard. 2002. Truth and Truthfulness. Princeton: Princeton University Press. Zaibert, Leo. 2014. "On the Matter of Suffering: Derek Parfit and the Possibility of Deserved Punishment." Criminal Law and Philosophy: 1-18. 